\title{
How Plant Functional Traits of Dominant Species Respond to Fencing and Water-Nitrogen Addition in Horqin Grassland, China
}

\author{
Xiyuan Yue ${ }^{1,2}$, Xiaoan $\mathrm{Zuo}^{2,3 *}$, Xueyong $\mathrm{Zhao}^{2,3}$, Peng $\mathrm{Lv}^{2,3}$, \\ Jiangbao Xia ${ }^{1 * *}$, Fanzhu $\mathbf{Q u}{ }^{1}$
}

${ }^{1}$ Shandong Key Laboratory of Eco-Environmental Science for Yellow River Delta, Binzhou University, Binzhou, China ${ }^{2}$ Urat Desert-Grassland Research Station, Northwest Institute of Eco-Environment and Resources, Chinese Academy of Science, Lanzhou, China

${ }^{3}$ Naiman Desertification Research Station, Northwest Institute of Eco-Environment and Resources, Chinese Academy of Sciences, Lanzhou, China

Received: 5 September 2019

Accepted: 3 November 2019

\begin{abstract}
Plant functional traits can reflect the response and adaptation of plant species to environmental changes. However, how plant functional traits of dominant species respond to the fencing, water and nitrogen additions in a sandy grassland ecosystem is still unclear. Here, a manipulative field experiment was conducted to investigate the effects of fencing, water and nitrogen addition on the functional traits of four dominant species (Pennisetum centrasiaticum, Cleistogenes squarrosa, Chenopodium acuminatum and Salsola collina) in Horqin sandy grassland. The results showed that nitrogen addition had a significant effect on plant height, specific leaf area (SLA), leaf nitrogen content (LNC), and leaf dry matter content (LDMC). Nitrogen addition increased plant height for C. squarrosa as well as SLA for $P$. centrasiaticum and $S$. collina, while reducing plant height for $P$. centrasiaticum and LDMC for $S$. collina. Also, nitrogen addition increased LNC for the four dominant species. Water addition reduced LDMC in grazing treatment, as well as plant height in fencing and nitrogen addition treatments. Compared to control treatment, nitrogen addition increased the strength of negative associations of LDMC with plant height and LNC. The results suggest that nitrogen addition plays an important role in determining the growth of the four dominant species, and water addition increases the competition of resource use among species in fencing and nitrogen addition treatments. Plants in sandy grassland can mediate the key functional traits to cope with alterations of water and nitrogen under the future global change scenarios.
\end{abstract}

Keywords: fencing, water and nitrogen addition, plant functional traits, dominant species, sandy grassland

*e-mail: zuoxa@1zb.ac.cn

**e-mail: xiajb@163.com 


\section{Introduction}

Grassland accounts for $41 \%$ of the terrestrial ecosystems in China [1], and also plays an important role in sustaining ecosystem function $[2,3]$. However, the degradation of grassland is still severe due to climate change and unreasonable human activities such as grazing [4, 5], and the negative effect of grazing on plant community diversity and primary productivity has been reported $[4,6]$. Moreover, Huang et al. [7] reported that precipitation decreased in Inner Mongolia, whereas nitrogen deposition increased due to agricultural and industrial activities [8]. Nitrogen supply not only increased aboveground biomass [9] but also impacted plant functional traits [10]. Species have different strategies to cope with environmental change [11], such as the different responses of functional traits of Leymus chinensis and Cleistogenes squarrosa to grazing in Inner Mongolia typical steppe [12]. However, the response of plant functional traits for perennials and annuals to fencing, water and nitrogen addition is still unclear in the field, especially in Horqin sandy grassland.

Plant functional traits are important in ecology, because they can respond to changes in environmental conditions at the individual level and also affect ecosystem structure and function [13, 14]. Recently, plant functional traits have been documented in response to climate changes [15] and grazing [16, 17]. The key plant functional traits such as plant height, specific leaf area (SLA), leaf dry matter content (LDMC) and leaf nitrogen content (LNC) not only strongly correlated with the relative growth rate and photosynthesis [18] but also linked to resource acquisition and environmental adaptation [19]. Moreover, plant height, SLA, LDMC and LNC are easy to be measured $[15,19,20]$. Here, these key functional traits were chosen in our study.

Horqin sandy grassland is located in the agropastoral zone [21], and the sandy grassland is very vulnerable to climate change and human activities [22]. The degradation of sandy grassland is mainly due to unreasonable land use management and heavy grazing [23, 24]. In recent years, more attempts had been adopted to restore the degraded sandy grassland. It has been reported that conservation practices such as fencing and decreased grazing intensity help to restore the degraded grassland ecosystem [23, 25]. Su et al. [26] showed that fencing not only increased the aboveground biomass, but also enhanced vegetation recovery in Horqin sandy land. However, species have different growth strategies in response to grazing [27], and the effect of fencing and grazing on plant functional traits is still rare in Horqin sandy grassland. Here, we selected two dominant perennial species (Pennisetum centrasiaticum and C. squarrosa) and two dominant annual species (Chenopodium acuminatum and Salsola collina) because these species are widespread in the sandy grassland and sensitive to environmental change [28].

In order to provide theoretical support for the sustainable development of sandy grassland in Horqin, we established a fencing, water and nitrogen addition experiment in the field. The object of this study was to investigate (1) how the functional traits of four dominant species respond to fencing, water and nitrogen addition treatments and (2) do nitrogen addition affect the relationships between functional traits.

\section{Materials and Methods}

\section{Study Area}

This study was conducted in Horqin sandy grassland near the Naiman Desertification Research Station of the Chinese Academy of Science $\left(42^{\circ} 57.83^{\prime} \mathrm{N}\right.$, $120^{\circ} 40.03^{\prime} \mathrm{E}, 364 \mathrm{~m}$ a.s.l.). The climate is characterized as typical semiarid continental. The mean annual precipitation is $360 \mathrm{~mm}$, and nearly $75 \%$ of the precipitation falls during the growing season (June to September) [21]. The average annual temperature is about $6.4^{\circ} \mathrm{C}$ [21]. The vegetation is dominated by P. centrasiaticum, C. squarrosa, C. acuminatum and $S$. collina. The soil is aeolian sandy soil according to the Chinese soil taxonomy classification system (http://www.resdc.cn).

\section{Experiment Design}

We set up a fencing, nitrogen and water addition experiment in a homogeneous sandy grassland in 2014 . There were eight treatments: grazing $(\mathrm{G})$, fencing $(\mathrm{F}), \mathrm{N}$ addition $(\mathrm{N})$, water addition $(\mathrm{W}), \mathrm{F}+\mathrm{N}, \mathrm{F}+\mathrm{W}, \mathrm{G}+\mathrm{W}+\mathrm{N}$ and $\mathrm{F}+\mathrm{W}+\mathrm{N}$. Forty-eight $8 \mathrm{~m} \times 8 \quad \mathrm{~m}$ plots were randomly arranged (six replicates for each treatment), and plots were separated from each other by a $1 \mathrm{~m}$ wide aisle. The grazing plots were grazed by cattle in early July and winter, respectively. The fenced plots were fenced with barbed wire. The plots with $\mathrm{N}$ addition treatment receive urea $10 \mathrm{~g} \mathrm{~N} \mathrm{~m}^{-2}$ month $^{-1}$ in April and July, respectively. $\mathrm{N}$ addition was applied by hand in the rainy days. The water addition treatment was watered by $30 \%$ of the monthly precipitation (from May to August) using the underground water nearby.

\section{Sampling}

We carried out the sampling at the peak of growing season (late August) in 2016. Four dominant plant species - two perennial species ( $P$. centrasiaticum and C. squarrosa) and two annual species (C. acuminatum and $S$. collina.) - were chosen as the study material. However, P. centrasiaticum, C. squarrosa and $S$. collina were not present in all plots. Sampled subplots were set in the center of each plot. We focused 
Table 1. ANOVA analysis of functional traits of dominant species responding to fencing, water and nitrogen additions.

\begin{tabular}{|c|c|c|c|c|c|c|c|c|}
\hline & \multicolumn{2}{|c|}{ Plant height } & \multicolumn{2}{|c|}{ SLA } & \multicolumn{2}{|c|}{ LDMC } & \multicolumn{2}{c|}{ LNC } \\
\hline & $F$ & $P$ & $F$ & $P$ & $F$ & $P$ & $F$ & $P$ \\
\hline Fencing & 3.09 & $\mathrm{~ns}$ & 0.45 & $\mathrm{~ns}$ & 0.88 & $\mathrm{~ns}$ & 0.00 & $\mathrm{~ns}$ \\
\hline Nitrogen & 5.19 & $*$ & 13.44 & $* *$ & 6.77 & $*$ & 272.72 & $* *$ \\
\hline Water & 0.56 & $\mathrm{~ns}$ & 0.34 & $\mathrm{~ns}$ & 0.37 & $\mathrm{~ns}$ & 0.90 & $\mathrm{~ns}$ \\
\hline Species & 93.94 & $* *$ & 44.27 & $* *$ & 323.08 & $* *$ & 30.44 & $* *$ \\
\hline Fencing $\times$ Nitrogen & 0.02 & $\mathrm{~ns}$ & 0.18 & $\mathrm{~ns}$ & 0.04 & $\mathrm{~ns}$ & 3.28 & $\mathrm{~ns}$ \\
\hline Fencing $\times$ Water & 7.04 & $*$ & 4.65 & $*$ & 7.32 & $*$ & 0.35 & $\mathrm{~ns}$ \\
\hline Nitrogen $\times$ Water & 5.67 & $*$ & 0.26 & $\mathrm{~ns}$ & 0.07 & $\mathrm{~ns}$ & 0.63 & $\mathrm{~ns}$ \\
\hline Species $\times$ Fencing & 2.37 & $\mathrm{~ns}$ & 0.38 & $\mathrm{~ns}$ & 0.43 & $\mathrm{~ns}$ & 0.44 & $\mathrm{~ns}$ \\
\hline Species $\times$ Nitrogen & 18.05 & $* *$ & 1.72 & $\mathrm{~ns}$ & 3.06 & $*$ & 14.79 & $* *$ \\
\hline Species $\times$ Water & 0.45 & $\mathrm{~ns}$ & 0.07 & $\mathrm{~ns}$ & 0.46 & $\mathrm{~ns}$ & 0.46 & $\mathrm{~ns}$ \\
\hline
\end{tabular}

Trait abbreviations are specific leaf area (SLA), leaf dry matter content (LDMC), leaf nitrogen content (LNC). $F$, F-values. $P$, Probabilities. *represents $P<0.05$, ** represents $P<0.01$, ns represents no significant $(P>0.05)$.

on four functional traits, including plant height, specific leaf area (SLA), leaf dry matter content (LDMC), and leaf nitrogen content (LNC) because these traits related to different plant functional strategies [29, 30]. The maximum plant height was measured using steel tape. 5 to 10 fully mature and healthy leaves of each dominant species were selected from 3-5 individuals in the plot in order to measure plant functional traits. The leaves were placed between moist papers in sealed plastic bags, and then stored in a refrigerator for laboratory analysis. SLA, LDMC and LNC were measured according to standard protocols [19]. LNC was determined using an elemental analyser (Costech ECS 4010, Italy), and LNC was expressed in mass $(\%)$.

\section{Data Analysis}

The effect of species, fencing, water and nitrogen addition on plant functional traits (plant height, SLA, LDMC and LNC) was performed using analysis of variance (ANOVA) under the general linear models (GLM), with species, fencing, water and nitrogen addition as fixed factors, and the plant functional traits as dependent variables. Multiple comparisons with leastsignificant difference (LSD) test procedures were made only when ANOVA tests were considered significant $(P<0.05)$. To illustrate the responses of plant functional traits to $\mathrm{N}$ addition, Pearson correlation analysis was used to analyze relationships between plant functional traits. The results were considered significant when $P<0.05$. Data analysis and mapping were performed by using software of SPSS19.0 and SigmaPlot12.0, respectively.

\section{Results}

\section{Functional Traits Respond to Fencing and Water-Nitrogen Addition}

$\mathrm{N}$ addition has a significant effect on all the measured functional traits compared to other treatments $(P<0.05$, Table 1$)$. $\mathrm{N}$ addition increased plant height, SLA and LNC while decreasing LDMC (Fig. 1). Plant functional traits were significantly different among species $(P<0.01$, Table 1). Plant height was higher in
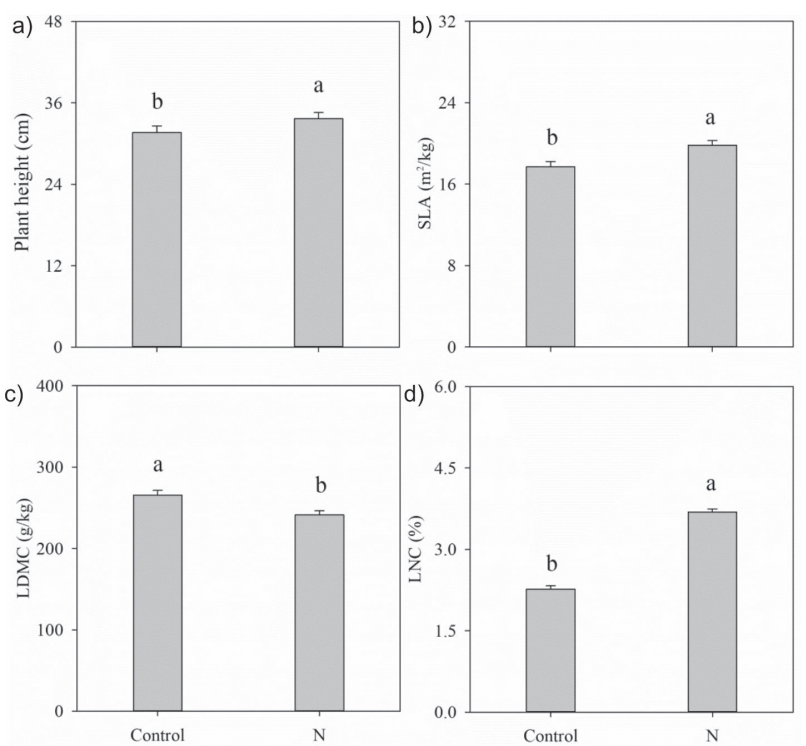

Fig. 1. Effects of $\mathrm{N}$ addition on plant functional traits. Trait abbreviations are specific leaf area (SLA), leaf dry matter content (LDMC), and leaf nitrogen content (LNC). Different letters represent significant differences at $P<0.05$. 
$P$. centrasiaticum and $C$. acuminatum than in $C$. squarrosa and $S$. collina. SLA and LDMC were higher in perennials ( $P$. centrasiaticum and C. squarrosa) than in annuals (C. acuminatum and $S$. collina). LNC was higher in $C$. acuminatum than in perennials and S. collina (Fig. 2).

There was a significant interaction between fencing and water addition on plant height, SLA and LDMC, while a significant interactive effect between $\mathrm{N}$ addition and water addition on plant height was found $(P<0.05$, Table 1). Water addition decreased LDMC in grazing treatment, and also decreased plant height in fencing and $\mathrm{N}$ addition treatments. Grazing increased LDMC in control (Fig. 2). Additionally, the significant interactive effects of $\mathrm{N}$ addition and species on plant height, LDMC and LNC were observed $(P<0.01$, Table 1$)$.
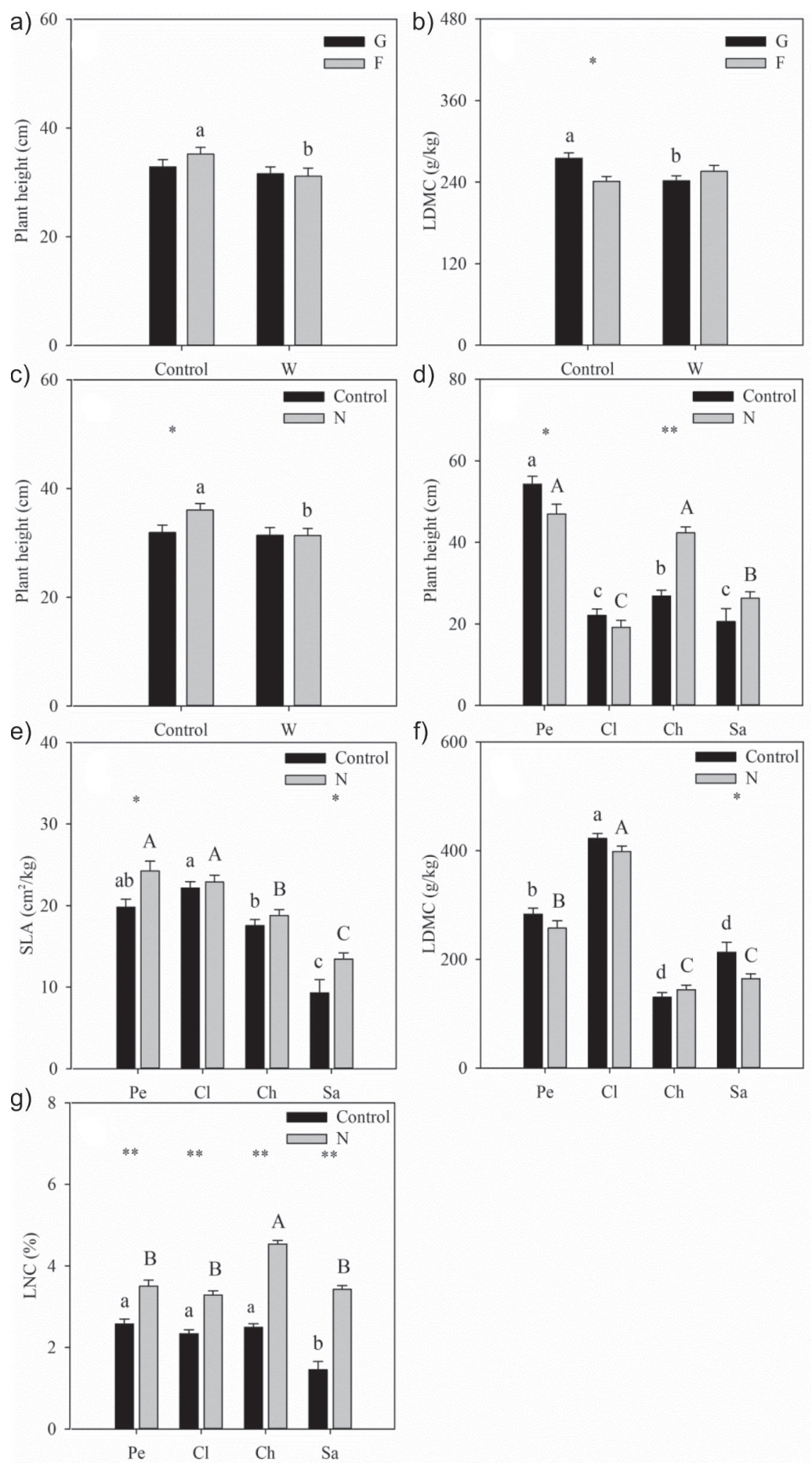

Pe

Fig. 2. Effects of fencing $\times$ water, nitrogen $\times$ water and species $\times$ nitrogen on plant functional traits. $(\mathrm{a}$ and $\mathrm{b}$, fencing $\times$ water; $\mathrm{c}$ and $\mathrm{d}$, nitrogen $\times$ water; $\mathrm{d}-\mathrm{g}$, species $\times$ nitrogen.). $\mathrm{F}$, fencing; $\mathrm{G}$, grazing; W, water addition; $\mathrm{N}$, nitrogen addition. Pe, P. centrasiaticum; $\mathrm{Cl}$, C. squarrosa; Ch, C. acuminatum; Sa, S. collina. Trait abbreviations are specific leaf area (SLA), leaf dry matter content (LDMC), leaf nitrogen content (LNC). Different letters represent significant differences at $P<0.05$. *represents $P<0.05$, ** represents $P<0.01$ 
$\mathrm{N}$ addition significantly increased plant height for $C$. acuminatum, while decreasing plant height for $P$. centrasiaticum $(P<0.05$, Fig. 2$)$. $\mathrm{N}$ addition increased SLA for perennials and annuals, and SLA of $P$. centrasiaticum and $S$. collina was significantly higher in $\mathrm{N}$ addition treatment than in control $(P<0.05)$. N addition decreased LDMC for $S$. collina, while it increased LNC for the four dominant species (Fig. 2).

\section{Relationships Between Functional Traits}

Correlation analysis showed that plant height was significantly and negatively correlated with LDMC in $\mathrm{N}$ addition treatment, while it was positively correlated with LNC in control and $\mathrm{N}$ addition treatments, respectively $(P<0.01$, Fig. 3$)$. SLA was positively associated with LDMC in control and
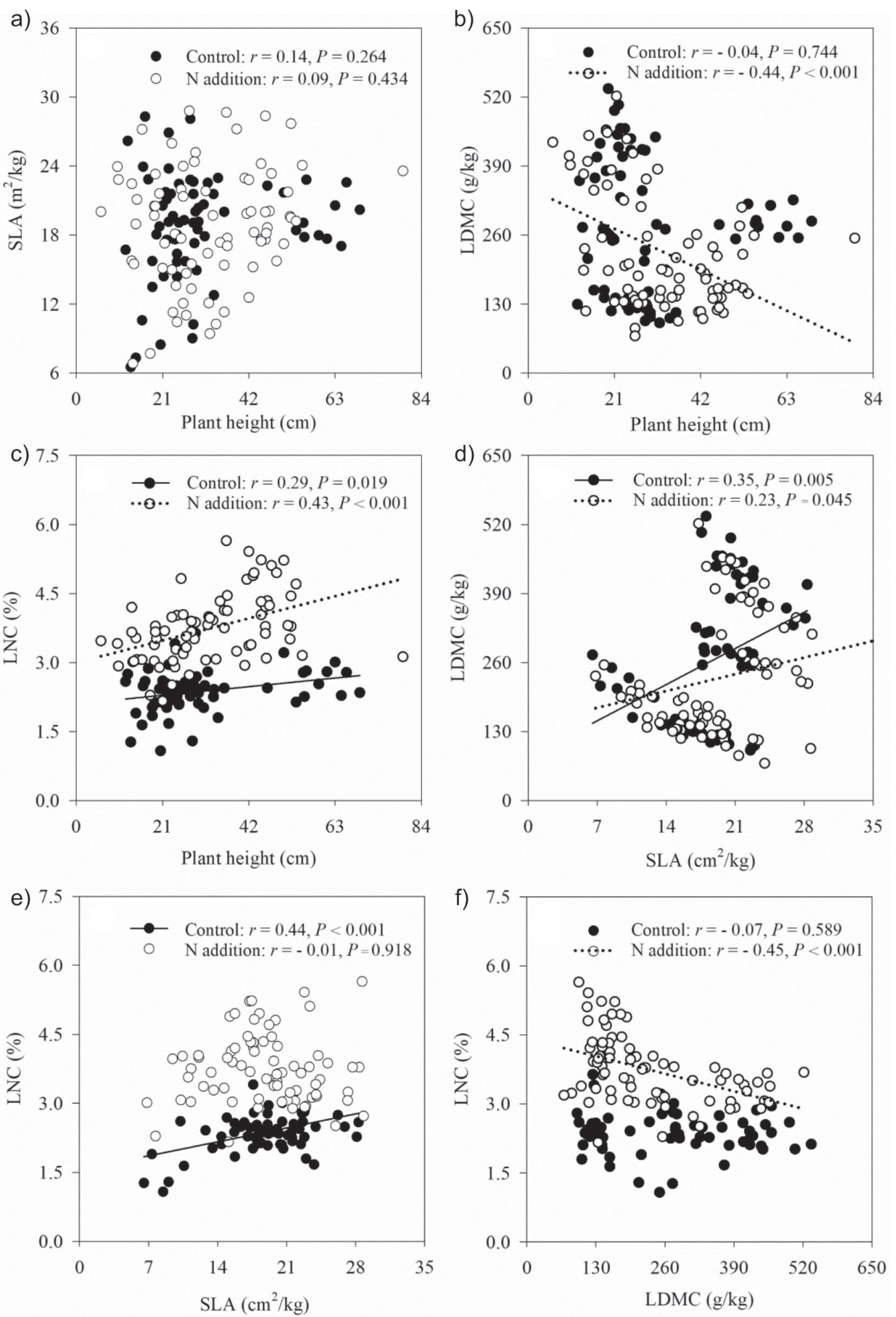

Fig. 3. Correlations between functional traits in control and $\mathrm{N}$ addition treatments. Trait abbreviations are specific leaf area (SLA), leaf dry matter content (LDMC), and leaf nitrogen content (LNC). 
$\mathrm{N}$ addition treatments, respectively $(P<0.05)$, and positively correlated with $\mathrm{LNC}$ in control $(P<0.01)$. Negative correlation between LDMC and LNC was found in $\mathrm{N}$ addition treatment $(P<0.01$, Fig. 3).

\section{Discussion}

We found that $\mathrm{N}$ addition increases plant height, SLA and LNC while reducing LDMC in Horqin sandy grassland. The result confirmed our previous finding that $\mathrm{N}$ addition has diverse effects on plant functional traits [31], and also in accordance with previous findings showing that SLA [32] and LNC [10, 31] increased with $\mathrm{N}$ supply. Because nitrogen is one of the important resources for plants to grow [33, 34], and $\mathrm{N}$ addition can improve soil nitrogen availability which promotes the photosynthesis of plants [10, 35]. Additionally, SLA was positively correlated with plant growth rates and reflected light capture and plant growth [36], and high SLA suggests that plants have a strong ability to maintain nutrition $[14,37]$. $\mathrm{N}$ supply promotes the photosynthesis of plants and results in high SLA, and accordingly low LDMC was observed. It is an important strategy for plants to adapt to environmental changes, especially $\mathrm{N}$ deposition.

SLA and LDMC were higher in perennials (C. squarrosa and $P$. centrasiaticum) than in annuals (C. acuminatum and S. collina) in our study. The higher SLA in perennials than in annuals is related to the differences of leaf area and leaf water content [38]. The result is in agreement with previous studies showed that SLA varied between leaves on the same plant and different species [39, 40]. However, the difference between LDMC is mainly due to the leaf water content of specific species. Because C. acuminatum and $S$. collina are annuals with succulent leaves [37], thus low LDMC for these two annuals.

Water addition had an insignificant effect on plant functional traits in our experiment, suggesting that functional traits were not altered by the water supply in the sandy grassland. However, previous findings showed that water addition has an effect on plant functional traits in a typical steppe [10], and plant height was low in dry conditions [41]. It is probably attributed to plants having been acclimated themselves to the local environment in Horqin sandy grassland, further suggesting that water addition is not a proper way to maintain the sustainable development of sandy grassland in Horqin because of the decline of groundwater caused by unreasonable irrigation and climate change in Horqin sandy land [22, 42]. Moreover, water addition reduced plant height in fencing and $\mathrm{N}$ addition treatments in our study, indicating that water addition interacted with fencing, and $\mathrm{N}$ supply is not favor plant growth in the sandy grassland. One explanation for this result is that water and $\mathrm{N}$ addition improved the soil resource availability, which enhanced competition among species in the use of available water and nitrogen. This result further supported the hypothesis that competition among species would be more profound under high resource conditions compared to less favorable conditions [36].

This study showed that $\mathrm{N}$ addition reduced the plant height of perennials ( $P$. centrasiaticum and C. squarrosa), while increasing the plant height of annuals (C. acuminatum and $S$. collina). Likewise, previous studies reported that high and low $\mathrm{N}$ addition treatments reduced the plant height of Mosla cavaleriei [32], while there was no significant effect from nitrogen addition on Mosla dianthera [32] and Pelargonium sidoides [43]. The result confirmed the different response of plant functional traits to $\mathrm{N}$ addition treatment $[31,32]$, and indicated that plant functional traits are strongly species-dependent [44]. This result further suggests that $\mathrm{N}$ addition favors the growth of annuals over perennials in the sandy grassland. We also found that $\mathrm{N}$ addition increased SLA and LNC for the four dominant species, and the result is in agreement with previous findings that $\mathrm{N}$ addition increased $\mathrm{LNC}$ for C. acuminatum in Horqin sandy grassland [45]. This is mainly due to $\mathrm{N}$ being the main limiting factor that determines plant growth in Horqin sandy grassland [45], and $\mathrm{N}$ addition may lessen $\mathrm{N}$ limitation by improving soil nitrogen availability [8]. $\mathrm{N}$ addition significantly reduced LDMC for $S$. collina in our experiment. The reason is that $S$. collina is an annual plant with succulent leaves, and $\mathrm{N}$ addition increased SLA for $S$. collina, which induced the reduction of LDMC.

Our study found a significant negative association between plant height and LDMC in $\mathrm{N}$ addition treatment. Such an association can be attributed to $\mathrm{N}$ addition promoting plant growth, and plants invest less dry matter content in the leaves, especially for $S$. collina. SLA was strongly and positively associated with LDMC in control and $\mathrm{N}$ addition treatments, indicating that plants exhibited high SLA and high LDMC in Horqin sandy grassland. LDMC reflects the investment of plants in dry matter content in leaves, and plants tend to accumulate more dry matter in poor-nutrition environmental conditions [20, 46]. The proportion of species with succulent leaves may also affect the relationships between SLA and LDMC [11], because these succulent species have low LDMC in control and $\mathrm{N}$ addition treatments compared to perennials. Thus, it is possible that the high SLA and high LDMC for plants in the control and nitrogen addition treatments. In addition, different relationships between SLA and LDMC have been found in previous experiments [46, 47], and the heterogeneity between different habitats is an important factor affecting the relationships [48, 49]. Previous studies have reported that SLA was positively related to $\operatorname{LNC}[20,38,50]$, and the relationships in control treatment confirmed this finding in our study. LDMC negatively associated with LNC in $\mathrm{N}$ addition treatment, suggesting that $\mathrm{N}$ supply favors the increase of LNC and the improvement of photosynthesis, and plants accumulated low dry mater content in leaves. Therefore, these results indicate that 
different species and their functional traits varied in different environmental conditions [46, 51], and plants use a combination of traits to cope with changing environments [52] - especially the alteration of nitrogen availability.

\section{Conclusions}

Our results clearly reveal that the fencing, water and nitrogen addition affect the different aspects of functional traits for the dominant species in Horqin sandy grassland. $\mathrm{N}$ addition is the main factor in regulating the growth of species in the sandy grassland, as it significantly increased LNC for the four dominant species. Moreover, water addition interacted with fencing and nitrogen addition decreased plant height, indicating that competition among species is more profound under high resource conditions than under unfavorable conditions. Importantly, nitrogen addition contributes to the significant association of LDMC with plant growth and LNC, and plants can alter the key functional traits to cope with $\mathrm{N}$ supply. These results further suggest that $\mathrm{N}$ deposition favors the growth of dominant species in the sandy grassland under future global change.

\section{Acknowledgements}

This study was supported by the National Natural Science Foundation of China (41622103 and 41571106) and Taishan Scholars Program of Shandong Province, China (J.B. Xia). We would like to thank all the members of Urat Desert-grassland Research Station and Naiman Desertification Research Station, Chinese Academy of Sciences (CAS), for their assistance with fieldwork.

\section{Conflicts of Interest}

The authors declare no conflict of interest.

\section{References}

1. LIU M.Z., WANG B.X., OSBORNE C.P., JIANG GM.. Chicken farming in grassland increases environmental sustainability and economic efficiency. PLoS One 8, e53977, 2013.

2. TILMAN D., WEDIN D., KNOPS J. Productivity and sustainability influenced by biodiversity in grassland ecosystems. Nature 379, 718, 1996.

3. MU S.J., CHEN Y.Z., LI J.L., JU W.M., ODEH I.O.A., ZOU X.L. Grassland dynamics in response to climate change and human activities in Inner Mongolia, China between 1985 and 2009. Rangeland J 35, 315, 2013.

4. WANG X.X., DONG S.K., SHERMAN R., LIU Q.R., LIU S.L., LI,Y.Y., WU Y. A comparison of biodiversity
- ecosystem function relationships in alpine grasslands across a degradation gradient on the Qinghai-Tibetan Plateau. Rangeland J 37, 45, 2015.

5. WU J.S., LI M., FIEDLER S., MA W.L., WANG X.T., ZHANG X.Z., TIETJEN B. Impacts of grazing exclusion on productivity partitioning along regional plant diversity and climatic gradients in Tibetan alpine grasslands. J Environ Manage 231, 635, 2019.

6. FEDRIGO J.K., ATAIDE P.F., FILHO J.A., OLIVEIRA L.V., JAURENA M., LACA E.A., OVERBECK G.E., NABINGER C. Temporary grazing exclusion promotes rapid recovery of species richness and productivity in a long-term overgrazed Campos grassland. Restor Ecol 26, 677, 2018.

7. HUANG J., SUN S.L., XUE Y., ZHANG J.C. Changing characteristics of precipitation during 1960-2012 in Inner Mongolia, northern China. MAP 127, 257, 2015.

8. LIU X.J., DUAN L., MO J.M., DU E.Z, SHEN J.L, LU X.K., ZHANG Y., ZHOU X.B., HE C.N., ZHANG FS.. Nitrogen deposition and its ecological impact in China: An overview. Environ Pollut 159, 2251, 2011.

9. LADWIG L.M., COLLINS S.L., SWANN A.L., XIA Y., ALLEN M.F., ALLEN E.B. Above- and belowground responses to nitrogen addition in a Chihuahuan Desert grassland. Oecologia 169, 177, 2012.

10. REN H.Y., XU Z.W., HUANG J.H., CLARK C., CHEN S.P, HAN X.G. Nitrogen and water addition reduce leaf longevity of steppe species. Ann Bot 107, 145, 2011.

11. WILSON P.J., THOMPSON K., HODGSON J.G. Specific leaf area and leaf dry matter content as alternative predictors of plant strategies. New Phytol 143, 155, 1999.

12. ZHENG S.X., LAN Z.C., LI W.H., SHAO R.X., SHAN Y.M., WAN H., TAUBE F., BAI Y.F. Differential responses of plant functional trait to grazing between two contrasting dominant $\mathrm{C} 3$ and $\mathrm{C} 4$ species in a typical steppe of Inner Mongolia, China. Plant Soil 340, 141, 2011.

13. VIOLLE C., NAVAS M.L., VILE D., KAZAKOU E., FORTUNEL C., HUMMEL I., GARNIER E. Let the concept of trait be functional! Oikos 116, 882, 2007.

14. DEBOUK H., DE BELLO F., SEBASTI M.-T. Functional trait changes, productivity shifts and vegetation stability in mountain grasslands during a short-term warming. PLoS One 10, e0141899, 2015.

15. ROSBAKH S., R MERMANN C., POSCHLOD P. Specific leaf area correlates with temperature: new evidence of trait variation at the population, species and community levels. Alp Bot 125, 79, 2015.

16. BÄR LAMAS M.I., LARREGUY C., CARRERA A.L., BERTILLER M.B. Changes in plant cover and functional traits induced by grazing in the arid Patagonian Monte. Acta Oecol 51, 66, 2013.

17. ZHANG J.H., HUANG Y.M., CHEN H.Y., GONG J.R., QI Y., LI E.G., WU X.C. Response of plant functional traits at species and community levels to grazing exclusion on Inner Mongolian steppe, China. The Rangeland J 40, 179, 2018.

18. WANG G. Leaf trait co-variation, response and effect in a chronosequence. J Veg Sci 18, 563, 2007.

19. CORNELISSEN J., LAVOREL S., GARNIER E., DIAZ S., BUCHMANN N., GURVICH D., REICH P., TER STEEGE H., MORGAN H., VAN DER HEIJDEN M. A handbook of protocols for standardised and easy measurement of plant functional traits worldwide. Aust $\mathbf{J}$ Bot 51, 335, 2003. 
20. QIN J., SHANGGUAN Z. Effects of forest types on leaf functional traits and their interrelationships of Pinus massoniana coniferous and broad-leaved mixed forests in the subtropical mountain, Southeastern China. Ecol Evol 9, 6922, 2019.

21. ZUO X.A., ZHAO X.Y., ZHAO H.L., ZHANG T.H., LI Y.L., WANG S.K., LI W.J., POWERS R. Scale dependent effects of environmental factors on vegetation pattern and composition in Horqin Sandy Land, Northern China. Geoderma 173, 1, 2012.

22. LI J., XU B., YANG X.C., QIN Z., ZHAO L.N., JIN Y.X., ZHAO F., GUO J. Historical grassland desertification changes in the Horqin Sandy Land, Northern China (19852013). Sci Rep 7, 3009, 2017.

23. ZHANG T.H., ZHAO H.L., LI S.G., ZHOU R.L. Grassland changes under grazing stress in Horqin sandy grassland in Inner Mongolia, China. N Z J Agric Res 47, 307, 2004.

24. WANG Y.F., ZHANG J.Q., TONG S.Q., GUO E.L. Monitoring the trends of aeolian desertified lands based on time-series remote sensing data in the Horqin Sandy Land, China. Catena 157, 286, 2017.

25. YUAN J.Y., OUYANG Z.Y., ZHENG H., XU W.H. Effects of different grassland restoration approaches on soil properties in the southeastern Horqin sandy land, northern China. Appl Soil Ecol 61, 34, 2012.

26. SU Y.Z., LI Y.L., CUI J.Y., ZHAO W.Z. Influences of continuous grazing and livestock exclusion on soil properties in a degraded sandy grassland, Inner Mongolia, northern China. Catena 59, 267, 2005.

27. FANSELOW N., SCH NBACH P., GONG X.Y., LIN S., TAUBE F., LOGES R., PAN Q., DITTERT K. Short-term regrowth responses of four steppe grassland species to grazing intensity, water and nitrogen in Inner Mongolia. Plant Soil 340, 279, 2011

28. ZHANG Q., DING Y., MA W.J., KANG S., LI X., NIU J.M., HOU X.Y., LI X.L., SARULA. Grazing primarily drives the relative abundance change of $\mathrm{C} 4$ plants in the typical steppe grasslands across households at a regional scale. Rangeland J 36, 565, 2014.

29. SIEFERT A., FRIDLEY J.D., RITCHIE M.E. Community functional responses to soil and climate at multiple spatial scales: when does intraspecific variation matter? PLoS One 9, e111189, 2014.

30. YUE X.Y., ZUO X.A., YU Q., XU C., LV P., ZHANG J., KNAPP, A.K., SMITH, M.D. Response of plant functional traits of Leymus chinensis to extreme drought in Inner Mongolia grasslands. Plant Ecol 220, 141, 2019.

31. MAO R., ZHANG X.H., SONG C.C. Effects of nitrogen addition on plant functional traits in freshwater wetland of Sanjiang Plain, Northeast China. Chin Geogr Sci 24, 674, 2014.

32. CAO Q.J., MENG W., YING G., CHANG S.X., ZHANG J.M., JIE C. Growth responses of two Mosla species to soil nitrogen and water supply. Bot Stud 51, 451, 2010.

33. DIREKVANDI S.N., ANSARI N.A., DEHCORDIE F.S. Effect of Different Levels of Nitrogen Fertilizer with Two Types of Bio-Fertilizers on Growth and Yield of Two Cultivars of Tomato (Lycopersicon esculentum Mill). Asian J Plant Sci 7, 755, 2008.

34. SONG M., LI X.M., JING S.S., LEI L.J., WANG J.L., WAN S.Q. Responses of soil nematodes to water and nitrogen additions in an old-field grassland. Appl Soil Ecol 102, 53, 2016.
35. MORIWAKI T., FALCIONI R., TANAKA F.A.O., CARDOSO K.A.K., SOUZA L.A., BENEDITO E., NANNI M.R., BONATO C.M., ANTUNES W.C. Nitrogen-improved photosynthesis quantum yield is driven by increased thylakoid density, enhancing green light absorption. Plant Sci 278, 1, 2019.

36. LEMKE I.H., KOLB A., GRAAE B.J., DE FRENNE P., ACHARYA K.P., BLANDINO C., BRUNET J., CHABRERIE O., COUSINS S.A.O., DECOCQ G., HEINKEN T., HERMY M., LIIRA J., SCHMUCKI R., SHEVTSOVA A., VERHEYEN K., DIEKMANN M. Patterns of phenotypic trait variation in two temperate forest herbs along a broad climatic gradient. Plant Ecol 216, 1523, 2015.

37. VENDRAMINI F., D AZ S., GURVICH D.E., WILSON P.J., THOMPSON K., HODGSON J.G. Leaf traits as indicators of resource-use strategy in floras with succulent species. New Phytol 154, 147, 2002.

38. GARNIER E., CORDONNIER P., GUILLERM J.L., SONI L. Specific leaf area and leaf nitrogen concentration in annual and perennial grass species growing in Mediterranean old-fields. Oecologia 111, 490, 1997.

39. WITKOWSKI E.T.F., LAMONT B.B. Leaf specific mass confounds leaf density and thickness. Oecologia 88, 486, 1991.

40. POWERS J.S., TIFFIN P. Plant functional type classifications in tropical dry forests in Costa Rica: leaf habit versus taxonomic approaches. Funct Ecol 24, 927, 2010.

41. SARANGI D., IRMAK S., LINDQUIST J.L., KNEZEVIC S.Z., JHALA A.J. Effect of Water Stress on the Growth and Fecundity of Common Waterhemp (Amaranthus rudis). Weed Sci 64, 42, 2016.

42. ZHAO Z.Z., LIN A.W., FENG J.D., YANG Q., ZOU L. Analysis of water resources in Horqin Sandy Land using multisource data from 2003 to 2010. Sustainability 8, 374, 2016.

43. MOFOKENG M.M., STEYN J.M., DU PLOOY C.P., PRINSLOO G., ARAYA, H.T. Growth of Pelargonium sidoides DC. in response to water and nitrogen level. S Afr J Bot 100, 183, 2015.

44. LV X.M., ZHOU G.S., WANG Y.H., SONG X.L. Effects of changing precipitation and warming on functional traits of zonal Stipa plants from Inner Mongolian grassland. J Meteorol Res 30, 412, 2016.

45. CHEN F., ZENG D., FAHEY T.J., YAO C., YU Z. Response of leaf anatomy of Chenopodium acuminatum to soil resource availability in a semi-arid grassland. Plant Ecol 209, 375, 2010.

46. RAOUDA A.H.K., MICHEL D., PIERRE T.J., SYLVAIN P., PABLO C. Variation in leaf traits through seasons and $\mathrm{N}$-availability levels and its consequences for ranking grassland species. J Veg Sci 16, 391, 2005.

47. LI Y.L., JOHNSON D.A., SU Y.Z., CUI J.Y., ZHANG T.H. Specific leaf area and leaf dry matter content of plants growing in sand dunes. Bot Bull of Acad Sinica 46, 127, 2005.

48. ZHUANG L., CHEN Y.N., LI W.H., WANG Z.K. Anatomical and morphological characteristics of Populus euphratica in the lower reaches of Tarim River under extreme drought environment. J Arid Land 3, 261, 2011.

49. GRIFFITH D.M., QUIGLEY K.M., ANDERSON T.M. Leaf thickness controls variation in leaf mass per area (LMA) among grazing-adapted grasses in Serengeti. Oecologia 181, 1035, 2016. 
50. HE J.S., WANG Z.H., WANG X.P., SCHMID B., ZUO W.Y., ZHOU M., ZHENG C.Y., WANG M.F., FANG J.Y. A test of the generality of leaf trait relationships on the Tibetan Plateau. New Phytol 170, 835, 2006.

51. WANG L.L., ZHAO G.X., LI M., ZHANG M.T., ZHANG L.F., ZHANG X.F., AN L.Z., XU S.J. C:N:P stoichiometry and leaf traits of halophytes in an arid saline environment, northwest China. PLoS One 10, e0119935, 2015.

52. OYARZABAL M., PARUELO J.M., DEL PINO F., OESTERHELD M., LAUENROTH W.K. Trait differences between grass species along a climatic gradient in South and North America. J Veg Sci 19, 183, 2008. 
